\title{
PENATAAN KAWASAN PARIWISATA AIR TERJUN HUMOGO
}

\author{
Ivo Era-Era Zalukhu ${ }^{1)}$, Irwan Wipranata ${ }^{2)}$ \\ 1) Program Studi S1 PWK, Fakultas Teknik, Universitas Tarumanagara, ivo.345150026@stu.untar.ac.id \\ 2) Program Studi S1 PWK, Fakultas Teknik, Universitas Tarumanagara, irwanwipranata@yahoo.co.uk

\begin{abstract}
Abstrak
Kawasan Pariwisata Air Terjun Humogo merupakan salah salah satu wisata air terjun yang terletak di Pulau Nias, tepatnya di Desa Fadoro, Kecamatan Gunungsitoli Idanoi, Kota Gunungsitoli, Provinsi Sumatera Utara. Rencana penataan Kawasan Pariwisata Air Terjun Humogo direncanakan berdasarkan Rencana Kerja Perangkat Daerah Dinas Pariwisata dan Kebudayaan Kota Gunungsitoli Tahun 2018, dimana penataan yang dilakukan bertujuan untuk menambah fasilitas dan prasarana yang mendukung pariwisata di Kawasan Pariwisata Air Terjun Humogo dan penyusunan Masterplan Kawasan Pariwisata Air Terjun Humogo, Kota Gunungsitoli. Kawasan Air Terjun Humogo terletak di Desa Fadoro dengan luas 15,5 ha dengan sebagian besar kawasan masih didominasi oleh hutan dan perkebunan. Kawasan Pariwisata Air Terjun Humogo merupakan salah satu destinasi wisata unggulan di Kota Gunungsitoli yang baru dibuka untuk umum pada akhir tahun 2018. Air terjun ini memiliki ciri khas yaitu air terjun yang bertingkat sehingga sangat menarik untuk dijelajahi oleh wisatawan serta memiliki kondisi alam yang masih sangat alami yang dikelilingi oleh pepohonan seperti pohon kelapa, pohon karet dan lain sebagainya. Namun area wisata ini masih memiliki kekurangan berupa sarana dan prasarana penunjang wisata sehingga diperlukan usulan fasilitas dan prasarana agar dapat meningkatkan daya tarik wisata Air Terjun Humogo. Analisis yang dilakukan adalah analisis kebijakan, analisis lokasi dan tapak, analisis best practice, analisis daya tarik wisata, analisis persepsi dan preferensi serta analisis kebutuhan ruang sehingga menghasilkan usulan dan Rencana Penataan Kawasan Pariwisata Air Terjun Humogo yang ditata dengan konsep ekowisata.
\end{abstract}

\section{Kata kunci: ekowisata; kawasan pariwisata air terjun; wisata alam; zonasi wisata}

\begin{abstract}
The Humogo Waterfall Tourism Area is one of the waterfall tours located on Nias Island, Fadoro Village, Gunungsitoli Idanoi Subdistrict, Gunungsitoli City, North Sumatra Province. The plan for structuring the Humogo Waterfall Tourism Area is planned based on the Regional Work Plan of the Gunungsitoli City Tourism and Culture Office in 2018, where the arrangement is aimed at adding facilities and infrastructure to support tourism in the Humogo Waterfall Tourism Area and the preparation of the Humogo Waterfall Tourism Area Master Plan, Gunungsitoli city. The Humogo Waterfall area is located in Fadoro Village with an area of 15.5 ha with most of the area still dominated by forests and plantations. The Humogo Waterfall Tourism Area is one of the leading tourist destinations in Gunungsitoli City, which was only opened to the public at the end of 2018. This waterfall has a distinctive characteristic of a multilevel waterfall so it is very interesting to be explored by tourists and has very natural conditions that are still very natural surrounded by trees such as coconut trees, rubber trees and so on. However, this tourism area still has shortcomings in the form of supporting tourism facilities and infrastructure so it is necessary to propose facilities and infrastructure in order to increase the tourist attraction of Humogo Waterfall. The analysis carried out is a policy analysis, site and site analysis, best practice analysis, tourist attraction analysis, perceptions and preferences analysis and analysis of spatial requirements so as to produce proposals and the Humogo Waterfall Tourism Area Planning Plan which is laid out with the concept of ecotourism
\end{abstract}

Keywords: ecotourism; nature tourism; tourist zoning; waterfall tourism region 


\section{PENDAHULUAN}

Indonesia merupakan salah satu negara yang memiliki keaekaragaman yang sangat banyak dimulai dari negara yang terdiri dari banyak pulau, keanekaragaman suku dan kebudayaan, memiliki sumber daya alam yang melimpah baik dari darat dan juga laut, serta memiliki potensi daerah pariwisata yang sangat banyak dari Sabang sampai Merauke. Perkembangan sektor pariwisata di Indonesia setiap tahun semakin berkembang pesat dikarenakan keindahan, keunikan dan keberagaman kekayaan alam yang ada di Indonesia. Perkembangan sektor pariwisata di Indonesia dapat dilihat dari data pengunjung wisatawan mancanegara yang terus meningkat

Salah satu keanekaragaman yang memiliki potensi utnuk dikembangkan di Indonesia yaitu sektor pariwisata yang sangat beragam. Oleh sebab itu pemerintah negara Indonesia menetapkan sektor pariwisata menjadi salah satu leading sector untuk mendukung perekonomian Negara Indonesia. Salah satu daerah dari Negara Indonesia yang memiliki salah satu potensi wisata yang baik terdapat di Sumatra Utara tepatnya di Pulau Nias, hal ini disebabkan karena pariwisata di Pulau Nias sebagian besar masih belum tersentuh atau dibenahi oleh pemerintah dalam upaya meningkatkan pariwisata di Pulau Nias. Kota Gunungsitoli yang merupakan salah satu kota di Pulau Nias mulai berbenah dalam meningkatkan sektor pariwisata di Pulau nias tepatnya di Kota Gunungsitoli.

Penataan Kawasan Pariwisata Air Terjun Humogo dilakukan berdasarkan Rencana Kerja (RENJA) Perangkat Daerah Dinas Pariwisata dan Kebudayaan Kota Gunungsitoli Tahun 2018 bahwa akan dilakukan penataan kawasan pariwisata Air Terjun Humogo di Desa Fadoro Kecamatan Gunungsitoli Idanoi Kota Gunungsitoli, kemudian akan dilanjutkan penataan lanjutan pada tahun 2019 salah satunya berupa pembuatan fasilitas pendukung di lokasi objek wisata Air Terjun Humogo Desa Fadoro Kecamatan Gunungsitoli Idanoi.

Kawasan Pariwisata Air Terjun Humogo merupakan salah satu destinasi wisata di Kota Gunungsitoli yang mulai diminati oleh pengunjung mulai dari tahun 2018. Air terjun ini memiliki ciri khas yaitu air terjun yang bertingkat sehingga sangat menarik untuk dijelajahi oleh wisatawan. Kawasan Pariwisata Air Terjun Humogo berlokasi di Desa Fadoro, Kecamatan Gunungsitoli, Kota Gunungsitoli. Alasan memilih topik Penataan Kawasan Air Terjun Humogo yaitu karena kawasan Air Terjun Humogo merupakan salah satu destinasi wisata yang mulai diminati dan ramai dikunjungi oleh wisatawan karena memiliki suasana alam yang sangat terasa dan air terjun yang memiliki keunikan tersendiri. Kemudian Dinas Pariwisata dan Kebudayaan Kota Gunungsitoli juga sudah merencanakan penataan destinasi wisata Air Terjun Humogo.

Rumusan masalah dari objek wisata Air Terjun Hunogo yaitu kurangnya fasilitas pendukung untuk meningkatkan kualitas dari destinasi wisata, kurangnya area komersial yang mendukung destinasi pariwisata seperti toko yang menyediakan atau menjual souvenir serta menjual makanan dan minuman di sekitar Kawasan Pariwisata Air Terjun Humogo, dan akses jalan menuju lokasi wisata yang masih belum memadai.

Tujuan penataan Kawasan Air Terjun Humogo yaitu untuk meningkatkan kualitas dan daya tarik dari Kawasan Pariwisata Air Terjun Humogo, Desa Fadoro, Kecamatan Gunungsitoli Idanoi, Kota Gunungsitoli.

\section{KAJIAN LITERATUR}

\section{Wisata}

Pengertian wisata menurut KBBI (Kamus Besar Bahasa Indonesia) adalah bepergian bersamasama (untuk memperluas pengetahuan, bersenang-senang, dan sebagainya); bertamasya. Menurut Undang-undang No. 10 Tahun 2009 tentang Kepariwisataan Bab 1 Pasal 1, wisata didefinisikan sebagai kegiatan perjalanan yang dilakukan oleh sesorang ataiu kelompok orang dengan mengunjungi suatu tempat atas tujuan rekreasi, pengembangan pribadi, serta mempelajari keunikan daya tarik wisata yang dikunjungi dalam jangka waktu yang sudah ditentukan sebelumnya. 


\section{Pariwisata}

Menurut Undang-Undang No. 9 Tahun 2009 tentang pariwisata, menyebutkan Pariwisata adalah berbagai macam kegiatan perjalanan atau sebagian dari kegiatan tersebut yang dilakukan secara sukarela serta bersifat sementara untuk menikmati objek dan daya tarik wisata yang di dukung berbagai fasilitas serta layanan yang di sediakan oleh masyarakat, pengusaha, dan pemerintah.

\section{Sarana dan Prasarana Pariwisata}

Sarana kepariwisataan adalah semua fasilitas yang memungkinkan agar prasarana pariwisata dapat hidup dan berkembang serta dapat memberikan pelayanan kepada wisatawan untuk memenuhi kebutuhan wisatawan. Sarana wisata merupakan kelengkapan daerah tujuan wisata yang diperlukan untuk melayani kebutuhan wisatawan dalam menikmati perjalannya. Suwantoro (2004:22)

Prasarana adalah segala fasilitas yang memungkan dapat melancarkan proses perekonomian berjalan dengan lancar sedemikian rupa sehingga memudahkan manusia untuk memenuhi kebutuhannya. Prasarana wisata merupakan sumber daya alam dan sumber aya manusia yang mutlak dibutuhkan oleh wisatawan dalam perjalannya menuju daerah tujuan wisata seperti listrik, jalan, air, jembatan, terminal, dan lain sebagainya. Suwantoro (2004:21)

\section{Penataan dan Perancanaan Ruang}

Menurut UU Republik Indonesia No.26 Tahun 2007 Tentang Penataan Ruang, Penataan Kawasan adalah salah satu upaya rekayasa sosial yang diselenggarakan di suatu lokasi/wilayah serta dilakukan beriringan dengan upaya menciptakan suatu sistem yang komprehensif terkait aktivitas yang berlangsung di suatu kawasan dengan mempetimbangkan kualitas lingkungan hidup di sekitarnya.

\section{Rencana Tata Ruang Pariwisata}

1) Terstruktur

Tatanan Zona Kegiatan memiliki sistem yang utuh antara zona pemanfaatan dan zona konservasi serta memiliki orientasi kawasan yang jelas melalui keberadaan suatu pusat kawasan sebagai orientasi pengunjung.

2) Terintegrasi

Tatanan kawasan/fungsi kegiatan yang menggambarkan hubungan fungsional dan spasial yang kompak dan efisien antara satu kegiatan dengan kegiatan yang lainnya.

3) Memiliki Orientasi Wilayah dan Gerbang yang Jelas

Orientasi gerbang memiliki arti untuk lebih menekankan tentang akses yang dilalui untuk mencapai lokasi pariwisata. Bentuk akses atau gerbang yang jelas sebagai area transisi dan area penerima ke kawasan.

Zona adalah kawasan atau area yang memiliki fungsi dan karakteristik lingkungan yang spesifik. Zoning merupakan sistem pengelompokan unsur-unsur yang mempunyai peranan fungsi yang sama. Sistem ini akan memberikan pengarahan dalam menentukan letak massa bangunan secara fisik. Penetapan zoning selalu berorientasi pada aktivitas.

\section{1) Zona Inti}

Zona inti ini merupakan komponen utama (main attraction) dalam sebuah atraksi wisata di suatu tempat yang dilengkapi dengan fasilitas pendukung. Menurut (Gunn, 1972) memberikan keterangan bahwa jika atraksi wisatanya berupa sebuah air terjun, maka yang disebut sebagai zona inti adalah jatuhnya air tersebut. 


\section{2) Zona Penyangga}

Zona penyangga ini berada di sekitar zona inti yang memisahkan antara zona inti (main attraction) dengan zona pemanfaatan/zona pelayanan (aktifitas dan fasilitas pendukung). Zona ini menjadi tanda bahwa seorang wisatawan akan segera memasuki suatu kawasan inti dari suatu atraksi wisata di lokasi tertentu.

\section{3) Zona Pelayanan}

Zona ini merupakan suatu zona yang diperuntukkan bagi penyiapan pelayanan dimana seluruh aktifitas dan fasilitas pendukung dikelompokan untuk wisatawan yang datang berkunjung ke lokasi wisata. Zona ini merupakan titik akhir transportasi menuju suatu atraksi wisata serta tempat penyediaan berbagai pelayanan untuk wisatawan seperti misalnya akomodasi, restoran dan sebagainya.

\section{Ekowisata}

Menurut peraturan menteri dalam negeri No.33 tahun 2009 tentang pengembangan ekowisata, ekowisata merupakan kegiatan wisata alam di daerah yang bertanggung jawab dengan memperhatikan unsur pendidikan, pemahaman dan dukungan terhadap usaha-usaha konservasi sumber daya alam, serta peningkatan pendapatan masyarakat lokal.

\section{METODE}

Data yang dikumpulkan selama proses penelitian adalah fisik dasar Kota Gunungsitoli, Kecamatan Gunungsitoli Idanoi dan Kawasan Pariwisata Air Terjun Humogo yang terdiri atas peta batas administrasi, pembagian wilayah, topografi, curah hujan dan iklim, dan penggunaan lahan. Data selanjutnya yaitu data kependudukan, sarana dan prasarana eksisting objek studi serta persepsi dan preferensi dari area objek studi.

Teknik pengumpulan data yang dilakukan terdiri atas metode pengumpulan data primer dan pengumpulan data sekunder. Teknik pengumpulan data primer merupakan teknik yang dilakukan secara langsung di tempat objek studi tanpa melalui media perantara seperti observasi lapangan, wawancara dan penyebaran kuesioner dan foto yang didapat dari survei langsung ke lokasi objek studi. Data sekunder diperoleh dari beberapa instansi terkait dalam penelitian serta berbagai sumber yang relevan seperti buku, jurnal, dokumen-dokumen pemerintah serta sumber dari internet yang dapat dipertanggungjawabkan seperti Dinas Pariwisata dan Budaya Kota Gunungsitoli, Badan Pusak Statistik Kota Gunungsitoli, serta studi pustaka/studi literature.

Analisis yang dilakukan adalah analisis kebijakan, analisis lokasi dan tapak yang terdiri atas analisis batas administrasi, aksesibilitas, proximity, penggunaan lahan, fasilitas, prasarana dan SWOT, analisis best practice, analisis daya tarik wisata, analisis persepsi dan preferensi yang terdiri atas profil responden, hubungan dan kebutuhan pengunjung, persepsi pengunjung dan preferensi pengunjung, dan analisis kebutuhan ruang yang terdiri atas proyeksi pengunjung dan program ruang. Pada analisis persepsi pengunjung menggunakan metode crosstab untuk mengetahui hubungan dan kebutuhan pengunjung. Output dari analisis persepsi pengunjung menggunakan diagram cartecius untuk menunjukkan tingkat kepentingan dan kepuasan terhadap kondisi fasilitas di area objek studi. Metode yang digunakan untuk analisis preferensi pengunjung menggunakan metode statistic (one sample test) dengan melihat nilai mean sample (test value $=3$ ). Tujuan dari penilitian menggunakan metode-metode tersebut adalah untuk mengetahui gambaran, deskripsi, faktual dan akurat dari data objek studi yang diteliti.

\section{DISKUSI DAN HASIL}

\section{Analisis Kebijakan}

Berdasarkan Rencana Kerja (RENJA) Perangkat Daerah Dinas Pariwisata dan Kebudayaan Kota Gunungsitoli Tahun 2018 bahwa objek wisata Air Terjun Humogo dapat ditata karena 
merupakan salah satu bagian dari kegiatan kerja Dinas Pariwisata Kota Gunungsitoli yaitu Penyusunan Master Plan Kawasan Pariwisata Air Terjun Humogo Kota Gunungsitoli dan juga didukung oleh rencana kegiatan yang dilakukan oleh Dinas Pariwisata dan Kebudayaan Kota Gunungsitoli yaitu penyediaan fasilitas pendukung di lokasi objek wisata Air Terjun Humogo yang terdiri atas pembuatan jalur pejalan kaki/jalan setapak/broadwalk/pedestrian, toilet/ruang ganti, gazebo dan pagar pembatas.

Sesuai pada Rencana Pembangunan Kawasan Pariwisata Kota Gunungsitoli dapat kita ketahui bahwa Kota Gunungsitoli merencanakan pembangunan di area-area wisata yang terdiri atas wisata dengan daya tarik primer dan daya tarik sekunder. Pada daya tarik sekunder pemerintah Kota Gunungsitoli juga merencanakan pengembangan pariwisata untuk wisata air terjun di area Kota Gunungsitoli. Selain dari penataan area wisata, Pemerintah kota Gunungsitoli fokus dalam pembangunan-pembangunan yang mendukung pengembangan pariwisata. Oleh sebab itu dapat disimpulkan bahwa Kawasan Pariwisata Air Terjun Humogo merupakan salah satu kawasan yang akan dibangun dan dikembangkan oleh Pemerintah Kota Gunungsitoli.

\section{Analisis Lokasi}

Analisis lokasi bertujuan untuk meneliti faktor-faktor eksternal yang mempengaruhi tapak objek studi. Berikut adalah batas-batas Kawasan Pariwisata Air Terjun Humogo. Aksesibilitas menuju Kawasan Pariwisata Air Terjun Humogo dari Kota DKI Jakarta dapat diakses menggunakan moda transportasi pesawat yang terdiri atas maskapai Garuda Indonesia dan Lion Air dengan harga tiket pesawat mulai dari Rp 1.100.000,00.- dan kisaran waktu \pm 2 jam 55 menit. Aksesibilitas dari Kota Gunungsitoli dapat diakses menggunakan kendaraan roda 2 dan roda 4 dengan kisaran waktu \pm 31 menit.

Kondisi jaringan jalan dari Kota Gunungsitoli menuju Air Terjun Humogo yaitu Jalan Raya Pelud Binaka yang tergolong lurus dengan lebar jalan 6 meter. Akses menuju Kawasan Pariwisata Air Terjun Humogo setelah melalui Jalan Raya Pelud Binaka yaitu Jalan Raya Humene Hilifanikha. Kondisi dari Jalan Raya Humene Hilifanikha sangat berbeda dengan Jalan Raya Pelud Binaka dikarenakan memiliki lebar jalan yang kecil yaitu 4 meter sehingga kendaraan roda 4 sedikit susah ketika berpapasan. Kondisi jalan ini juga sudah diaspal namun di beberapa bagian terdapat jalan yang masih berlubang

Fasilitas tempat wisata yang mendukung di Kawasan Pariwisata Air Terjun Humogo secara keseluruhan tergolong jauh dari lokasi objek wisata. Hal ini disebabkan oleh ketidaktersediaan fasilitas tersebut di Kawasan Pariwisata Air Terjun Humogo. Proximity dengan kawasan wisata unggulan di Kota Gunungsitoli yang terdekat yaitu objek wisata Air Terjun MBaho Ndra yang berjarak 2,6 km dari Kawasan Air Terjun Humogo dan objek wisata rohani dan bangunan gereja di Desa Dahana dan Desa Ombolata berjarak 3,6 km dan 1,5 km. Kedua destinasi wisata ini tergolong dekat sehingga wisatawan Air Terjun Humogo dapat mengunjungi kedua objek wisata ini dengan mudah.

\section{Analisis Tapak}

Tapak dari Objek Studi Kawasan Pariwisata Air Terjun Humogo terdiri dari penggnaan beberapa penggunaan lahan yang terdiri atas air terjun seluas $0,7 \mathrm{ha}(4,52 \%)$, hunian seluas 0,12 ha( $0,77 \%)$, hutan seluas 14,3 ha(92,26\%), parkir seluas 0.02 ha(0,13\%) dan daerah perservasi seluas $0,36 \mathrm{ha}(2,32 \%)$. 


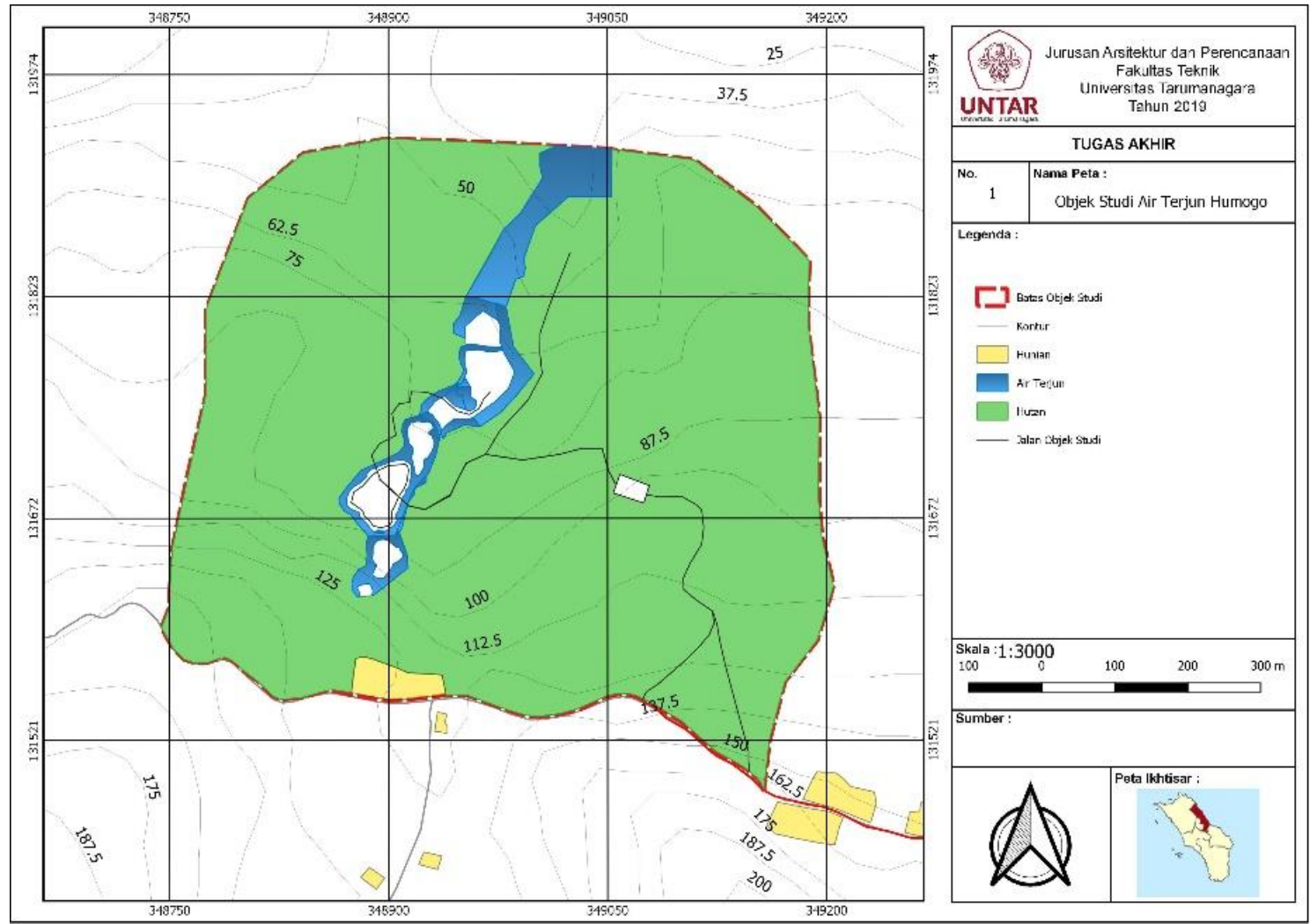

Gambar 1. Peta Objek Studi Air Terjun Humogo Sumber: Penulis, 2019

Fasilitas dan prasarana yang tersedia di Kawasan Pariwisata Air Terjun Humogo masih sangat kurang untuk mendukung kawasan wisata. Beberapa fasilitas yang belum tersedia yaitu seperti fasilitas air bersih, pos keamanan, homestay, rumah makan dan pos titik jaga. Dan untuk fasilitas lainnya juga masih kurang seperti tempat sampah, listrik, area parkir, warung dan toilet umum sehingga diperlukan usulan dan rekomendasi fasilitas dan prasarana di Kawasan Pariwisata Air Terjun Humogo

Tabel 1. Usulan Fasilitas dan Prasarana Kawasan Pariwisata Air Terjun Humogo

\begin{tabular}{|c|c|c|c|}
\hline No & Prasarana & Ketersediaan & Usulan \\
\hline 1 & $\begin{array}{l}\text { Jaringan } \\
\text { Jalan }\end{array}$ & $\begin{array}{l}\text { Belum } \\
\text { Memadai }\end{array}$ & $\begin{array}{l}\text { Jalan dari akses pintu masuk menuju kawasan parkir perlu } \\
\text { dilakukan pengaspalan terutama pada turunan jalan } \\
\text { sehingga mempermudah pengunjung untuk memasuki } \\
\text { area wisata. }\end{array}$ \\
\hline 2 & $\begin{array}{l}\text { Listrik dan } \\
\text { Penerangan }\end{array}$ & $\begin{array}{l}\text { Belum } \\
\text { Memadai }\end{array}$ & $\begin{array}{l}\text { Diharapkan dengan terbangunnya fasiltas wisata yang } \\
\text { mencukupi, prasarana jaringan listrik dapat menjangkau } \\
\text { fasilitas-fasilitas tersebut }\end{array}$ \\
\hline 3 & Air Bersih & $\begin{array}{l}\text { Belum } \\
\text { Memadai }\end{array}$ & $\begin{array}{l}\text { Penyediaan prasarana air bersih tentunya akan sangat } \\
\text { penting untuk mencukupi kebutuhan air bersih pada } \\
\text { bangunan-bangunan yang direncanakan seperti } \\
\text { penginapan, warung dan restoran }\end{array}$ \\
\hline 4 & $\begin{array}{l}\text { Tempat } \\
\text { Sampah }\end{array}$ & $\begin{array}{l}\text { Belum } \\
\text { Memadai }\end{array}$ & $\begin{array}{l}\text { Pada kondi eksisting kebersihan dari objek wisata di kelola } \\
\text { oleh masyarakat setempat yang tinggal di sekitar kawasan } \\
\text { wisata. Oleh sebab itu perlu perencanaan pembangunan } \\
\text { TPS untuk pengelolaan sampah di area kawasan wisata. }\end{array}$ \\
\hline 5 & $\begin{array}{l}\text { Jaringan } \\
\text { Komunikasi }\end{array}$ & $\begin{array}{l}\text { Cukup } \\
\text { Memadai }\end{array}$ & $\begin{array}{l}\text { Provider yang tersedia di Kawasan Pariwisata Air Terjun } \\
\text { Humogo yaitu provider Telkomsel. Usulan untuk } \\
\text { kedepannya perlu peningkatan tower seperti provider XL } \\
\text { yang kini sudah tersedia di Kota Gunungsitoli. }\end{array}$ \\
\hline
\end{tabular}




\begin{tabular}{|c|c|c|c|}
\hline No & Prasarana & Ketersediaan & Usulan \\
\hline 1 & Area Parkir & $\begin{array}{c}\text { Belum } \\
\text { Mencukupi }\end{array}$ & $\begin{array}{l}\text { Luas dari area parkir yang masih kurang menyebabkan } \\
\text { volume untuk menampung kendaraan menjadi terbatas } \\
\text { sehingga dibutuhkan penambahan fasilitas parkir untuk } \\
\text { menampung jumlah kendaraan yang dapat di parkir pada } \\
\text { kawasan tersebut }\end{array}$ \\
\hline 2 & Penginapan & $\begin{array}{l}\text { Belum } \\
\text { Tersedia }\end{array}$ & $\begin{array}{l}\text { Di area sekitar penataan belum tersedia penginapan untuk } \\
\text { wisatawan sehingga dibutuhkan pembangunan } \\
\text { penginapan yang mencukupi. }\end{array}$ \\
\hline 3 & $\begin{array}{l}\text { Rumah } \\
\text { Makan }\end{array}$ & $\begin{array}{l}\text { Belum } \\
\text { Tersedia }\end{array}$ & $\begin{array}{l}\text { Perlu dibangun fasilitas rumah makan yang menyajikan } \\
\text { makanan-makanan khas daerah Nias dan juga minuman } \\
\text { seperti air kelapa yang diolah karena di sekitar kawasan } \\
\text { wisata banyak pohon kelapa sehingga dapat menjadi ciri } \\
\text { khas tersendiri untuk kawasan air terjun Humogo }\end{array}$ \\
\hline 4 & $\begin{array}{l}\text { Pos } \\
\text { Keamanan / } \\
\text { Penjualan } \\
\text { tiket masuk }\end{array}$ & $\begin{array}{l}\text { Belum } \\
\text { tersedia }\end{array}$ & $\begin{array}{l}\text { Perlu dibangun pos keamanan untuk menjaga keamanan di } \\
\text { area kawasan wisata dan mengantisipasi hal-hal yang tidak } \\
\text { diinginkan. Kemudian untuk pos penjualan tiket masuk } \\
\text { perlu dibangun di area jalan masuk menuju kawasan wisata } \\
\text { untuk mengontrol wisatawan yang berkunjung di Kawasan } \\
\text { Pariwisata Air Terjun Humogo. }\end{array}$ \\
\hline 5 & Warung & Kurang & $\begin{array}{l}\text { Warung yang tersedia di Kawasan Pariwisata Air Terjun } \\
\text { Humogo masih sangat kurang sehingga perlu ditambah dan } \\
\text { dibangun dengan lebih baik untuk memberikan pelayanan } \\
\text { yang lebih baik kepada pengunjung. }\end{array}$ \\
\hline
\end{tabular}

Sumber: Penulis, 2019

\section{Analisis Daya Tarik Wisata}

Kegiatan wisata yang terdapat di Kawasan Pariwisata Air Terjun Humogo masih sangat minim. Sehingga membuat daya tarik wisata di Kawasan Pariwisata Air Terjun Humogo terkesan biasa saja. Untuk menambah daya tarik wisata, maka diusulkan rekomendasi penambahan kegiatan wisata yang dibagi menjadi kegiatan wisata darat dan kegiatan wisata air terjun. Berikut adalah rekomendasi kegiatan wisata di Kawasan Pariwisata Air Terjun Humogo:

Tabel 2. Rekomendasi Kegiatan Wisata

\begin{tabular}{|c|c|c|c|}
\hline No & Kegiatan & Jenis & Usulan/Rekomendasi \\
\hline \multirow{3}{*}{1} & \multirow{3}{*}{$\begin{array}{l}\text { Wisata } \\
\text { rekreasi } \\
\text { (Darat) }\end{array}$} & $\begin{array}{l}\text { Menikmati } \\
\text { Pemandangan }\end{array}$ & $\begin{array}{l}\text { Pembuatan tempat bersantai serta tempat-tempat yang digunakan } \\
\text { untuk spot berfoto bagi pengunjung sehingga wsiatawan } \\
\text { terfasilitasi untuk menikmati pemandangan }\end{array}$ \\
\hline & & Kuliner & $\begin{array}{l}\text { Penyediaan restaurant atau rumah makan yang menyediakan } \\
\text { makanan-makanan khas daerah Nias }\end{array}$ \\
\hline & & Flying Fox & $\begin{array}{l}\text { Penyediaan atraksi wisata seperti flying fox akan membuat Kawasan } \\
\text { Pariwisata Air Trjun Humogo menjadi lebih menarik yang didukung } \\
\text { oleh area kawasan air terjun yang bertingkat-tingkat dari atas ke } \\
\text { bawah sehingga pengunjung dapat melihat area air terjun secara } \\
\text { keseluruhan }\end{array}$ \\
\hline 2 & $\begin{array}{l}\text { Wisata } \\
\text { rekreasi } \\
\text { (Air) }\end{array}$ & $\begin{array}{l}\text { Berenang di } \\
\text { Telaga Air } \\
\text { Terjun }\end{array}$ & $\begin{array}{l}\text { Penyediaan fasilitas-fasiltas yang mendukung untuk berenang serta } \\
\text { meningkatkan pengelolaan yang lebih baik terhadap area berenang } \\
\text { di Air Terjun Humogo }\end{array}$ \\
\hline
\end{tabular}

Sumber: Penulis, 2019

\section{Analisis Best Practice}

Analisis ini bertujuan untuk membahas mengenai objek wisata air terjun yang memiliki karakteristik yang mirip dengan Kawasan Pariwisata Air Terjun Humogo dan tempat wisata yang sudah ditata maupun dikelola dari segi fasilitas dan prasarana yang mendukukng kawasan pariwisata. Objek wisata yang dijadikan benchmarking adalah Air Terjun Tegenungan Gianyar, 
Bali dan Air Terjun Kedung Pedut, Yogyakarta

Dalam melakukan analisis benchmarking tidak hanya membandingkan fasilitas, prasarana dan kegiatan wisata yang terdapat di objek wisata Air Terjun Tegenungan dan Air Terjun Kedung Pedut. Analisis ini juga mengacu pada kriteria pengembangan ekowisata.

Berikut adalah key success dari kedua objek benchmarking yang dapat menajdi acuan dalam penataan Kawasan Pariwisata Air Terjun Humogo:

1) Pada kriteria konservasi yaitu fasilitas pendukung yang dibangun tidak merusak lingkungan dan disesuaikan dengan karakteristik objek wisata

2) Partisipasi masyarakat dalam melestarikan serta membantu penyediaan jasa pariwisata serta akomodasi penginapan

3) Kesadaran masyarakat dalam kegiatan konservasi objek air terjun dan turut serta dalam melestarikan kawasan air terjun

4) Wisatawan dapat menghargai kearifan lokal yang ada di sekitar kawasan wisata

5) Akomodasi dan fasilitas yang disediakan menggunakan jasa masyarakat lokal

6) Terdapat regulasi yang mengatur standar kelayakan penginapan atau homestay sesuai dengan kondisi lokasi wisata

7) Mengembangkan paket-paket wisata yang mengedepankan budaya dan tradisi lokal sehingga menjadi daya tarik sendiri dan mendukung konservasi budaya lokal

Selain penerapan konsep ekowisata dan key success, kegiatan dan fasilitas pendukung wisata yang ada di benchmarking juga akan diterapkan di Kawasan Pariwisata Air Terjun Humogo. berikut adalah kegiatan dan fasilitas pendukung yang akan diterapkan di Kawasan Pariwisata Air Terjun Humogo:

Tabel 3. Kegiatan dan Fasilitas Wisata yang dapat diterapkan

\begin{tabular}{ll}
\hline Kegiatan Wisata & \multicolumn{1}{c}{ Fasilitas Wisata } \\
\hline Flying Fox & Warung makan/Restourant \\
\hline Sepeda Gantung & Tempat Pemandian \\
\hline & Gardu Pandang \\
\hline & Tempat Penginapan atau homestay \\
\hline & Pusat Informasi
\end{tabular}

Sumber: Penulis, 2019

\section{Analisis Persepsi dan Preferensi Pengunjung}

Analisis ini bertujuan untuk mengetahui persepsi dan preferensi pengunjung yang berwisata di Kawasan Pariwisata Air Terjun Humogo. Untuk mengetahui persepsi pengunjung, pengumpulan data dilakukan dengan penyebaran kuesioner selama 3 hari pada tanggal 5 sampai 8 Desember 2019, dimulai pada hari Jumat sampai hari Senin. Berdasarkan hasil pembagian kuesioner, penulis berhasil mendapat 100 responden yang bersedia untuk mengisi kuesioner penelitian

Analisis hubungan dan kebutuhan pengunjung menggunakan metode Crosstab dengan mencari tahu hubungan antara variabel profil pengunjung di Kawasan Pariwisata Air Terjun Humogo. Berikut adalah grafik hasil crosstab hubungan tempat tinggal dengan moda transportasi, hubungan tempat tinggal dengan frekuensi pengunjung, dan hubungan tempat tinggal dengan tujuan berkunjung:

Berdasarkan hasil analisis hubungan tempat tinggal dengan moda transportasi, hubungan tempat tinggal dengan jumlah berkunjung, dan hubungan tempat tinggal dengan tujuan berwisata. Berikut adalah kesimpulan dari ketiga analisis tersebut:

a. Hubungan tempat tinggal dengan moda tranportasi

Untuk menuju Kawasan Pariwisata Air Terjun Humogo pengunjung memerlukan aksesibilitas yang baik sehingga segala moda transportasi dapat digunakan. Ketersediaan area parkir juga sangat penting untuk menampung moda transportasi yang digunkan seperti bus dan mobil.

b. Hubungan tempat tinggal dengan frekuensi berkunjung 
Lokasi dari Kawasan Pariwisata Air Terjun Humogo yang terletak di Kota Gunungsitoli mempengaruhu frekuensi berkunjung dari masyarakat Kota Gunungsitoli. Semakin dekat dengan lokasi wisata maka frekuensi pengunjung akan semakin meningkat, hal ini dapat kita ketahui juga dari responden dari Kabupaten Nias yang memiliki frekuensi berkunjung di atas 3 kali sebesar $33 \%$.

c. Hubungan tempat tinggal dengan tujuan berkunjung

Wisatawan yang mengunjungi Kawasan Pariwisata Air Terjun Humogo rata-rata bertujuan untuk berwisata di area tersebut. Oleh sebab itu perlu ditambah sarana dan prasaran penunjang daerah wisata dan juga menambah kegiatan-kegiatan wisata selain berenang dan melihat pemandang. Pembangunan yang dilakukan juga berdasar pada prinsip ekowisata agar tidak merusak dan tetap menjaga kelestarian lingkungan.

Berdasarkan tabel tingkat kepentingan dan tingkat kinerja di atas maka dihasilkan diagram cartesius yang dibagi menjadi 4 klarifikasi prioritas (prioritas utama, prioritas rendah, dipertahankan, dan diabaikan). Berikut adalah diagram cartesius yang menjelaskan 4 klarifikasi prioritas di Kawasan Pariwisata Air Terjun Humogo:

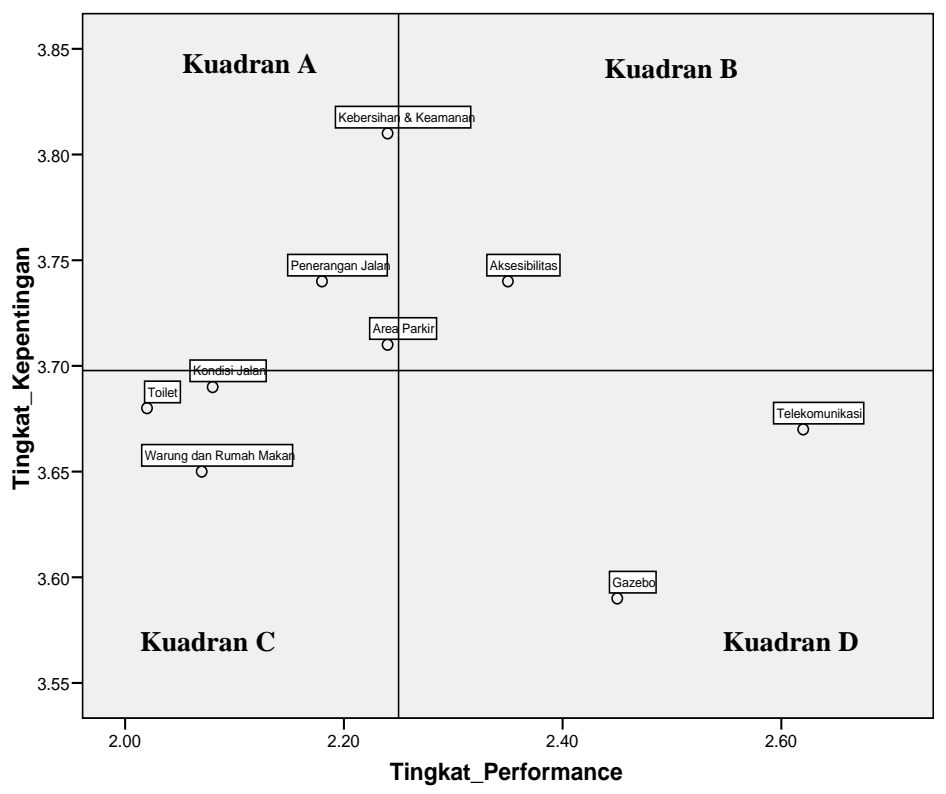

Gambar 2. Diagram Tingkat Kepentingan dan Tingkat Kinerja Fasilitas dan Prasarana Sumber: Penulis, 2019

Berikut adalah tabel dari masing-masing klasifikasi fasilitas di Kawasan Air Terjun Humogo:

Tabel 4. Klasifikasi dan Strategi Pengembangan Fasilitas dan Prasarana Kawasan Air Terjun Humogo

\begin{tabular}{|c|c|c|c|c|c|}
\hline \multirow[b]{2}{*}{ No } & \multirow[b]{2}{*}{ Faktor } & \multicolumn{4}{|c|}{ Klasifikasi } \\
\hline & & $\begin{array}{c}\text { Kuadran A } \\
\text { (Prioritas Utama) }\end{array}$ & $\begin{array}{c}\text { Kuadran B } \\
\text { (Dipertahank } \\
\text { an) }\end{array}$ & $\begin{array}{c}\text { Kuadran C } \\
\text { (Prioritas } \\
\text { Rendah) }\end{array}$ & $\begin{array}{l}\text { Kuadran D } \\
\text { (Diabaikan) }\end{array}$ \\
\hline \multirow[b]{2}{*}{1} & Fasilitas & & & Toilet & \\
\hline & $\begin{array}{c}\text { Penduku } \\
\text { ng }\end{array}$ & Area Parkir & Aksesibilitas & $\begin{array}{c}\text { Warung \& } \\
\text { Rumah Makan }\end{array}$ & Gazebo \\
\hline \multirow[b]{2}{*}{2} & \multirow{2}{*}{$\begin{array}{c}\text { Prasaran } \\
\text { a }\end{array}$} & Penerangan Jalan & & & \\
\hline & & $\begin{array}{c}\text { Kebersihan \& } \\
\text { Keamanan }\end{array}$ & - & Kondisi Jalan & Telekomunikasi \\
\hline
\end{tabular}

Sumber: Penulis, 2019 
Analisis preferensi pengunjung bertujuan untuk mengetahui tingkat kebutuhan sarana dan prasarana yang dapat menunjang kegiatan wisata di Kawasan Pariwisata Air Terjun Humogo Metode yang digunakan yaitu metode statistic (one sample test) dengan melihat nilai mean sample (test value $=3$ ).

\section{$\mathrm{HO}: \mu \leq 3$}

$\mathrm{H} 1: \mu>3$

Hasil Signifikansi $(\alpha=0.05)$ :

- Sig. < $\alpha$, maka Reject HO / HO ditolak / H1 diterima (cukup bukti bahwa fasilitas/wahana yang direncanakan sesuai dengan kebutuhan pengunjung)

- Sig > $\alpha$, maka Do Not Reject HO / HO diterima (tidak cukup bukti bahwa fasilitas/wahana yang direncanakan sesuai dengan kebutuhan pengunjung)

Berikut merupakan hasil output dari kuesioner yang telah diberikan kepada responden mengenai rencana penambahan dan penataan fasilitas/wahana kegiatan wisata Air Terjun Humogo:

Tabel 5. Preferensi Pengunjung terhadap Rencana Penambahan Fasilitas/Wahana

\begin{tabular}{|c|c|c|c|c|}
\hline $\begin{array}{l}\text { Rencana } \\
\text { Fasilitas/ } \\
\text { Wahana }\end{array}$ & $\mathbf{N}$ & Mean & Sig. & Keterangan \\
\hline $\begin{array}{l}\text { Pusat } \\
\text { Informasi }\end{array}$ & 100 & 3,76 & ,000 & $\begin{array}{l}\text { Reject HO, cukup bukti bahwa penambahan pusat } \\
\text { informasi sesuai dengan preferensi pengunjung }\end{array}$ \\
\hline ATM & 100 & 3,51 & ,000 & $\begin{array}{l}\text { Reject } \mathrm{HO} \text {, cukup bukti bahwa penambahan ATM sesuai } \\
\text { dengan preferensi pengunjung }\end{array}$ \\
\hline $\begin{array}{l}\text { Rumah } \\
\text { Makan/Rest } \\
\text { aurant }\end{array}$ & 100 & 3,68 & ,000 & $\begin{array}{l}\text { Reject HO, cukup bukti bahwa penambahan Rumah } \\
\text { Makan/Restaurant sesuai dengan preferensi } \\
\text { pengunjung }\end{array}$ \\
\hline $\begin{array}{l}\text { Pusat } \\
\text { Souvenir }\end{array}$ & 100 & 3,75 & 000 & $\begin{array}{l}\text { Reject H0, cukup bukti bahwa penambahan Pusat } \\
\text { Souvenir sesuai dengan preferensi pengunjung }\end{array}$ \\
\hline $\begin{array}{l}\text { Fasilitas } \\
\text { Penginapan }\end{array}$ & 100 & 3,62 & ,000 & $\begin{array}{l}\text { Reject } \mathrm{HO} \text {, cukup bukti bahwa penambahan Fasilitas } \\
\text { Penginapan sesuai dengan preferensi pengunjung }\end{array}$ \\
\hline $\begin{array}{l}\text { Lokasi } \\
\text { Gathering }\end{array}$ & 100 & 3,65 & ,000 & $\begin{array}{l}\text { Reject HO, cukup bukti bahwa penambahan Lokasi } \\
\text { Gathering sesuai dengan preferensi pengunjung }\end{array}$ \\
\hline $\begin{array}{l}\text { Tempat } \\
\text { Pemandian }\end{array}$ & 100 & 3,71 & ,000 & $\begin{array}{l}\text { Reject HO, cukup bukti bahwa penambahan Tempat } \\
\text { Pemandian sesuai dengan preferensi pengunjung }\end{array}$ \\
\hline Flying Fox & 100 & 3,48 & ,000 & $\begin{array}{l}\text { Reject } \mathrm{HO} \text {, cukup bukti bahwa penambahan Kegiatan } \\
\text { Wisata Flying Fox sesuai dengan preferensi pengunjung }\end{array}$ \\
\hline $\begin{array}{l}\text { Sepeda } \\
\text { Gantung }\end{array}$ & 100 & 2,79 & ,025 & $\begin{array}{l}\text { Do Not Reject HO, tidak cukup bukti bahwa } \\
\text { penambahan Kegiatan wisata sepeda gantung sesuai } \\
\text { dengan preferensi pengunjung }\end{array}$ \\
\hline
\end{tabular}

Sumber: Penulis, 2019

\section{Analisis Kebutuhan Ruang}

Analisis kebutuhan ruang bertujuan untuk mengidentifikasi kebutuhan ruang yang akan dijadikan kawasan wisata di Kawasan Pariwisata Air Terjun Humogo. Jumlah dari kebutuhan fasilitas dihitung berdasarkan jumlah pengunjung dan proyeksi pengunjung serta standar pembangunan fasilitas di Kawasan Pariwisata Air Terjun Humogo. Berdasarkan hasil wawancara dengan pihak dari Dinas Pariwisata dan Kebudayaan Kota Gunungsitoli bahwa jumlah pengunjung di Kawasan Pariwisata Air Terjun Humogo pada akhir minggu (weekend) yaitu sebanyak 150 hingga 200 pengunjung. Untuk menghitung proyeksi pengunjung maka 
diasumsikan laju pertumbahan pengunjung sebesar $20 \%$ per tahun. Maka berikut ini adalah proyeksi pengunjung 5 tahun ke depan dengan menggunakan rumus metode geometri.

$\begin{array}{lll} & & \text { Pt }=\text { Po. }(1+r) \mathbf{t} \\ \text { Pt } & = & \text { Jumlah Pengunjung pada tahun } \mathrm{t} \\ \text { Po } & = & \text { Jumlah Pengunjung pada tahun dasar } \\ \mathrm{t} & = & \text { jangka waktu } \\ \mathrm{r} & = & \text { laju pertumbuhan pengunjung (\%) }\end{array}$

Tabel 6. Proyeksi Pengunjung Kawasan Pariwisata Air Terjun Humogo

\begin{tabular}{cc}
\hline Tahun & Jumlah Pengunjung \\
\hline 2018 & 67.200 \\
\hline 2019 & 80.640 \\
\hline 2020 & 96.768 \\
\hline 2021 & 116.122 \\
\hline 2022 & 129.346 \\
\hline 2023 & 167.215 \\
\hline
\end{tabular}

Sumber: Penulis, 2019

Untuk menghitung kebutuhan fasilitas maka jumlah pengunjung yang digunakan diambil proyeksi jumlah pengunjung pada tahun 2023. Jumlah pengunjung perhari pada tahun 2003 yaitu 458 jiwa. Dalam melakukan penataan maka diperlukan pembagian zona perancanaan. Pembagian zona di Kawsana Pariwisata Air Terjun Humogo dibagi atas 3 zona yaitu :

a. Zona Inti

Zona inti mempunyai luas 2,8 ha yang berada di kawasan zona penyangga dan zona pelayanan. Kawasan ini berfungsi untuk mempertahankan keutuhuan dari air terjun terutama pada bagian goa yang merupakan sumber air dari objek wisata air terjun.

b. Zona Penyangga

Zona penyangga pada Kawasan Pariwisata Air Terjun Humogo memiliki luas 4,8 ha yang memiliki fungsi mendukung atau melindungi zona inti. Pada zona ini ditambahkan kegiatankegiatan wisata yang mengutamakan kelestarian alam serta fasilitas-fasilitas pendukung yang ramah lingkungan untuk mmemenuhu kebutuhan pariwisata.

c. Zona Pengembangan

Zona Pelayanan/Pengembagan pada Kawasan Pariwisata Air Terjun Humogo memiliki luas 7,9 ha yang diperuntukkan untuk pengembangan sarana pariwisata. Pada zona ini direncanakan untuk penyediaan akomodasi untuk wisatawan serta fasilitas dan prasarana pendukung kegiatan wisata di sekitar Kawasan Pariwisata Air Terjun Humogo

Tabel 7. Tabel Kebutuhan Ruang

\begin{tabular}{|c|c|c|c|c|}
\hline \multirow{2}{*}{ Zona } & \multirow{2}{*}{ Fasilitas } & \multicolumn{2}{|c|}{ Luas } & \multirow{2}{*}{ Sumber } \\
\hline & & $\left(m^{2}\right)$ & (Ha) & \\
\hline \multirow[t]{2}{*}{1} & Gazebo & 460 & 0,046 & $\begin{array}{c}\text { Standar Arsitektur Ernst } \\
\text { Neufert (1994 : 203) }\end{array}$ \\
\hline & Tempat Pemandian & 20 & 0.002 & Penulis \\
\hline \multicolumn{2}{|c|}{ Total Kebutuhan Lahan } & 480 & 0,048 & \\
\hline \multicolumn{2}{|c|}{ Persentase } & & $1,71 \%$ & \\
\hline \multirow{5}{*}{2} & Pusat Informasi/TIC & 78 & 0,007 & Permenpar \\
\hline & Pusat Souvenir/Kios Cinderamata & 321 & 0,032 & Permenpar \\
\hline & Warung/Rumah Makan/Pusat Kuliner & 1.282 & 0,128 & Permenpar \\
\hline & Toilet & 1.021 & 0,102 & $\begin{array}{c}\text { Standar Arsitektur Ernst } \\
\text { Neufert (1994: 203) }\end{array}$ \\
\hline & Ruang Ganti/Ruang Bilas & 805 & 0,080 & $\begin{array}{l}\text { Standar Arsitektur Ernst } \\
\text { Neufert (1994: 203) }\end{array}$ \\
\hline
\end{tabular}




\begin{tabular}{|c|c|c|c|c|}
\hline \multirow{6}{*}{ Zona } & \multirow{2}{*}{ Fasilitas } & \multicolumn{2}{|c|}{ Luas } & \multirow{2}{*}{ Sumber } \\
\hline & & $\left(m^{2}\right)$ & $(\mathrm{Ha})$ & \\
\hline & Pos Keamanan & 9 & 0,001 & penulis \\
\hline & ATM & 18 & 0,001 & Penulis \\
\hline & Musholla & 164 & 0,016 & SNI \\
\hline & Wisata Flying Fox & - & - & Penulis \\
\hline \multicolumn{2}{|c|}{ Total Kebutuhan Lahan } & 3.698 & 0,369 & \\
\hline \multicolumn{2}{|c|}{ Persentase } & & $7,50 \%$ & \\
\hline \multirow{5}{*}{3} & Area parkir & 1500 & 0,150 & dishub \\
\hline & Pusat Informasi/TIC & 78 & 0,007 & Permenpar \\
\hline & Guesthouse & 6588 & 0,658 & penulis \\
\hline & Pos Keamanan & 9 & 0,001 & penulis \\
\hline & Klinik & 108 & 0,010 & SNI \\
\hline \multicolumn{2}{|c|}{ Total Kebutuhan Lahan } & 8.283 & 0,828 & \\
\hline \multicolumn{2}{|c|}{ Persentase } & & $10,48 \%$ & \\
\hline
\end{tabular}

Sumber: Penulis, 2019

Konsep penataan yang digunakan yaitu konsep ekowisata karena konsep ekowisata mengutamakan kegiatan wisata alam yang bertanggung jawab dengan memperhatikan unsur pendidikan, pemahaman dan dukungan terhadap usaha-usaha konservasi sumber daya alam, serta peningkatan masyarakat lokal sehingga konsep ini sangat mendukung penataan Kawasan Pariwisata Air Terjun Humogo yang keadaan alamnya masih perlu dijaga tanpa merusak keadaan alam yang sudah tersedia. Rencana penggunaaan lahan pada Kawasan Pariwisata Air Terjun Humogo disesuaikan dengan keadaan topografi kawasan Air Terjun dan tetap mempertahankan kualitas alam area wisata.

Tabel 8. Rencanan Penggunaan Lahan

\begin{tabular}{lcc}
\hline Jenis Penggunaan Lahan & Luas (Ha) & Persentase (\%) \\
\hline Fasilitas & 1.11 & 7,16 \\
\hline Komersial & 0.16 & 1,03 \\
\hline Air Terjun & 0,7 & 4,52 \\
\hline Penginapan & 0,65 & 4,29 \\
\hline Hunian Eksisting & 0,12 & 0,77 \\
\hline Hutan \& Sirkulasi & 12,76 & $\mathbf{8 2 , 3 2}$ \\
\hline \multicolumn{1}{c}{ TOTAL } & $\mathbf{1 5 , 5}$ & $\mathbf{1 0 0}$ \\
\hline
\end{tabular}

Sumber: Penulis, 2019

Bangunan di Kawasan Pariwisata Air Terjun Humogo tetap menggunakan material yang tidak merusak lingkungan dan disesuaikan dengan kebutuhan pengunjung. Untuk menambah daya tarik wisata maka untuk konsep bangunan menggunakan konsep rumah khas adat Nias yang melambangkan budaya masyarakat Nias. Konsep bangunan ini dapat ditambahkan pada homestay atau pada pintu gerbang, atau pada bangunan-bangunan lainnya.

Jaringan jalan utama pada Kawasan Pariwisata Air Terjun Humogo direncanakan dengan lebar ROW sebesar $11 \mathrm{~m}$ sehingga bisa dilalui oleh sepeda motor, mobil dan bus pariwisata. Jaringan jalan setapak pada Kawasan Pariwisata Air Terjun Humogo direncanakan menggunakan jalur Boardwalk yang merupakan jalur pejalan kaki yang biasanya terbuat dari kayu. Boardwalk dapat dibangun disepanjang sungai atau pantai yang membantu pejalan kaki untuk menempuh medan yang sulit seperti di kawasan hutan, sungai dan lain sebagainya. 


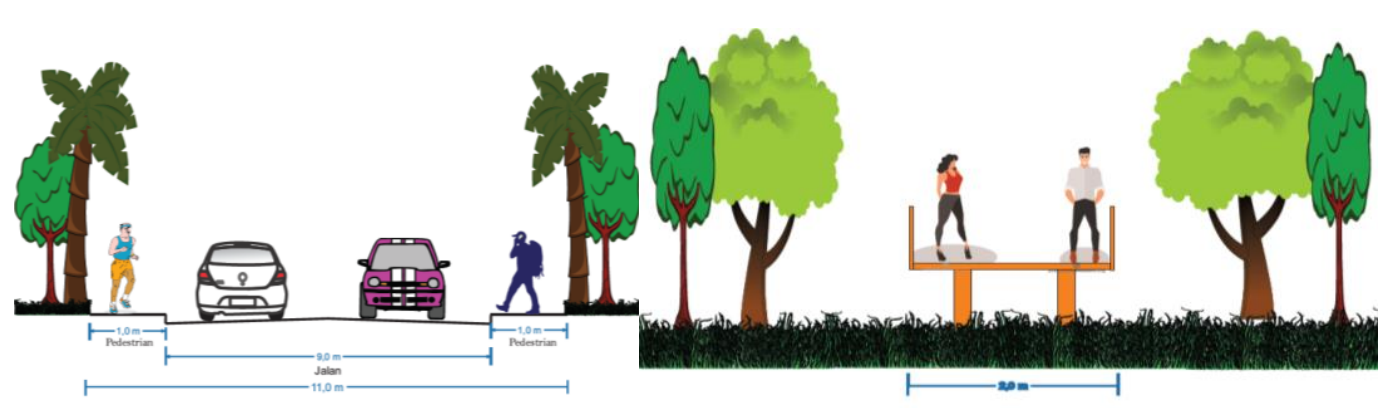

Gambar 3. Potongan Jalan Utama dan Potongan Boardwalk Sumber: Penulis, 2019

Masterplan dari Kawasan Pariwisata Air Terjun Humogo terdiri atas kawasan komersial dan area penginapan serta penambahan gazebo dan lampu penerangan. Penambahan fasilitas tersebut diharapkan dapat meningkatkan kualitas dari Kawasan Pariwisata Air Terjun Humogo. Berikut merupakan rencana penataan Kawasan Pariwisata Air Terjun Humogo Desa Fadoro, Kecamatan Gunungsitoli Idanoi, Kota Gunungsitoli dengan menggunakan konsep ekowisata:

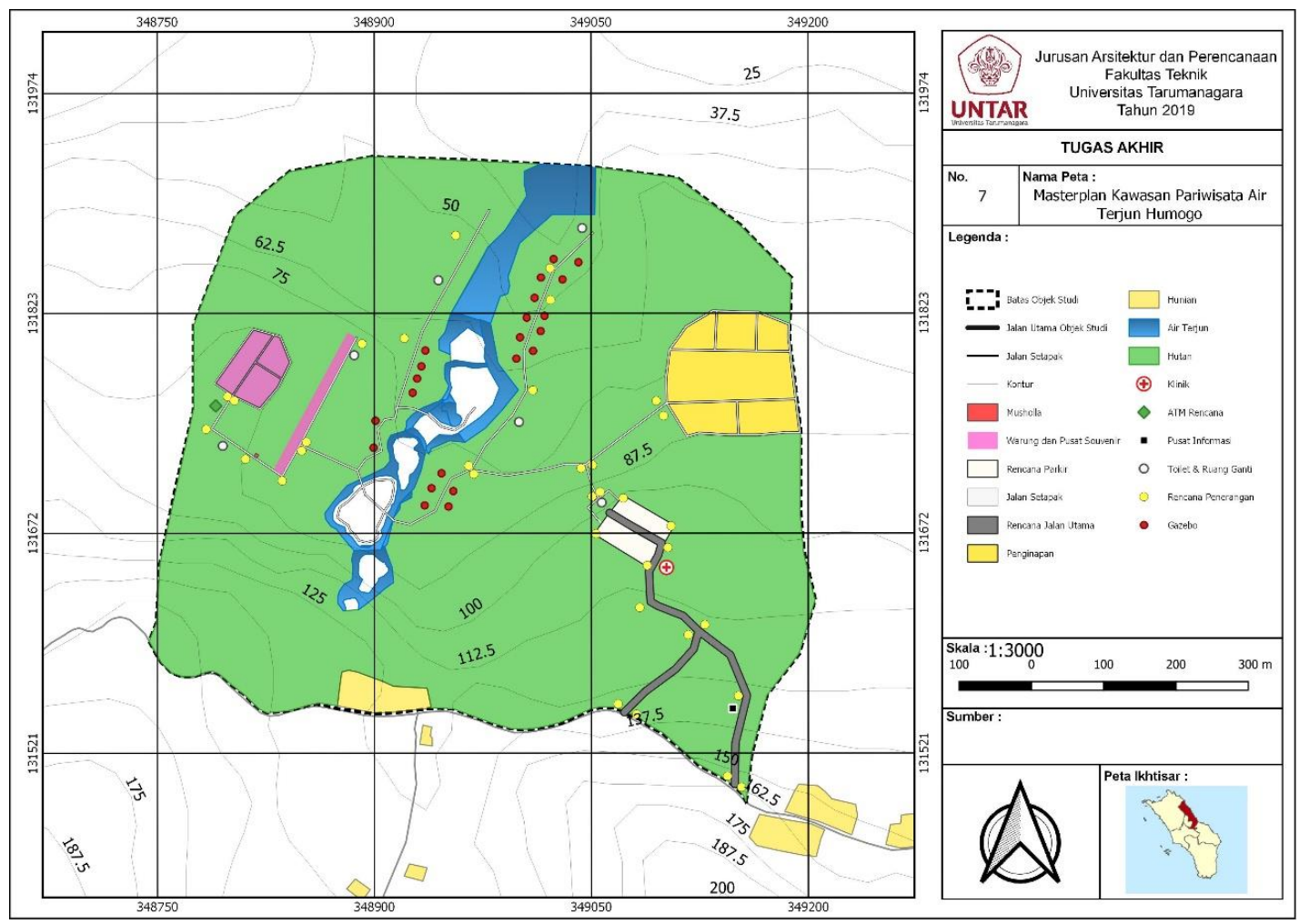

Gambar 4. Masterplan Kawasan Pariwisata Air Terjun Humogo Sumber: Penulis, 2019

\section{KESIMPULAN DAN SARAN}

\section{Kesimpulan}

1) Kawasan Pariwisata Air Terjun Humogo merupakan salah satu dari 17 destinasi wisata unggulan di Kota Gunungsitoli yang masih baru dan memiliki kondisi alam yang sangat baik.

2) Pemerintah Kota Gunungsitoli merencanakan pengembangan daerah-daerah wisata yang dimuat di dalam Rencana Kerja (RENJA) Perangkat Daerah Dinas Pariwisata dan Budaya dan Kota Gunungsitoli serta Peraturan Daerah Kota Gunungsitoli tentang Rencana Pembangunan Kawasan Strategis Pariwisata Kota (KSPK).

3) Penataan Kawasan Pariwisata Air Terjun Humogo ditata dengan konsep ekowisata sehingga tetap menjaga keadaan lingkungan daerah wisata. 
4) Penataan Kawasan Pariwisata Air Terjun Humogo dibagi menjadi 3 zona yaitu zona inti, zona penyangga dan zona pengembangan. Pembangunan fasilitas di Kawasan Pariwisata Air Terjun Humogo disesuaikan dengan fungsi dari masing-masing zona

5) Kawasan Pariwisata Air Terjun Humogo memiliki banyak potensi sebagai area wisata yang menarik karena tidak hanya menyajikan keadaan alam yang alami melainkan memiliki keunikan tersendiri yang dapat mengundang perhatian wisatawan.

\section{Saran}

1) Pemerintah dan masyarakat lokal yang berada disekitar Kawasan Pariwisata Air Terjun Humogo harus bekerja sama untuk merencanakan dan mengembangkan wisata Air Terjun Humogo sehingga masyarakat lokal dapat berkontribusi dan mendapat lapangan kerja di bidang pariwisata

2) Pengenalan Kawasan Pariwisata Air Terjun Humogo sebaiknya lebih diperkuat lagi agar wisatawan yang datang tidak hanya dari Pulau Nias melainkan bersal dari luar Pulau Nias hingga wisatawan asing

3) Kegiatan wisata yang ada di Kawasan Pariwisata Air Terjun Humogo perlu diperbanyak lagi untuk meningkatkan serta mendukung wisata Air Terjun Humogo.

4) Memanfaatkan hasil-hasil alam dan budaya terutama budaya Nias dalam penerapan rencana pembangunan dan rencana pengelolaan sehingga memiliki ciri khas yang menarik terutama bagi wisatawan dari luar Pulau Nias.

\section{REFERENSI}

Dokumen Teknis Peraturan Zonasi. (t.thn.). Diambil kembali dari https://docplayer.info/68118575-Perumusan-dokumen-teknis-peraturan-zonasi-kode-unitkompetensi-f45-pz-buku-informasi.html

Gunungsitoli, B. K. (2018). Kecamatan Gunungsitoli Idanoi Dalam Angka 2018. Kecamatan Gunungsitoli Dalam Idanoi Angka 2018, 1-29.

Gunungsitoli, B. K. (2018). Kota Gunungsitoli Dalam Angka 2018. Kota Gunungsitoli Dalam Angka 2018, 29-52.

Indonesia, K. B. (2019, Maret 14). Kamus Besar Bahasa Indonesia. Diambil kembali dari Kamus Besar Bahasa Indonesia: https//kbbi.kemdikbud.go.id/entri/wisata

Irawan, K. (2010, September 19). Potensi Objek Wisata Air Terjun Serdang Sebagai Daya Tarik Wisata Di Kabupaten Labuhan Batu Utara. Diambil kembali dari Repotisori Institusi Universitas Sumatera Utara: http://repository.usu.ac.id/handle/123456789/18824

Marpaung, H. (2002). Pengantar Pariwisata. Bandung: Alfabeta.

Maryani, E. (2009). Diktat Kuliah Geografi Pariwisata. Bandung.

Muljadi, A. (2009). Kepariwisataan dan Perjalanan. Jakarta: PT Raja Grafindo Persada.

Neufert, Ernst, Jilid 1, Data Arsitek, Jakarta : Erlangga

Now, S. A. (2013, Juni 25). Perhitungan Kebutuhan Fasilitas Wisata. Diambil kembali dari Study: http://studyandlearningnow.blogspot.com/2013/06/perhitungan-kebutuhan-fasilitaswisata.html

Suwantoro, G. (2004). Dasar-dasar Pariwisata. Penerbit Andi Yogyakarta

Undang-Undang Republik Indonesia No.26 Tahun 2007 Tentang Penataan Ruang. Indonesia:Pemerintah Republik Indonesia. 